\section{International Journal of \\ Advances in Scientific Research and Engineering (ijasre)}

DOI: 10.31695/IJASRE.2019.33447
E-ISSN : 2454-8006

Volume 5, Issue 7

July - 2019

\title{
The Role of Infrastructure in Indonesia's Economic Growth
}

\author{
Hanifatul Khurriah and Nurul Istifadah* \\ Department of Economics and Business \\ Airlangga University \\ Surabaya, East Java \\ Indonesia
}

\begin{abstract}
This study examines the relationship of public capital, especially infrastructure to economic growth in Indonesia. This study uses a growth model derived from aggregate production functions and the generalized method of moment (GMM) estimation techniques to estimate public infrastructure capital as explanatory power in the growth model. This research innovates from previous research on the relationship of infrastructure and economic growth at the regional level with disaggregation of types of infrastructure. Four types of infrastructure are estimated: roads, energy, water, and telecommunications. We use a panel of data from 34 provinces in Indonesia, during the 2011-2017 period. The results of this study provide general evidence water and telecommunication have a positive contribution to economic growth with different values. The negative and significant results are surprising for road infrastructure. This result is contrary to the expectations and many previous researchers but relevant to one study in China. A negative significant still means that infrastructure is good. This problem can be explained through the U-shaped infrastructure and growth investment relationship which gives a sign of crowding out the effect of private capital if the infrastructure investment is too dominant. The right strategy is needed to reduce inefficiency because too much infrastructure investment has the potential to reduce growth.
\end{abstract}

Keywords: Economic Growth, Infrastructure, Panel Data, Generalized Method Of Moment, Growth Model.

\section{INTRODUCTION}

Infrastructure is a manifestation of development policies to overcome gaps, increase growth, and economic inclusion (IMF, 2018). State expenditure in infrastructure is one of the government's efforts to encourage economic growth in addition to spending in the field of human resources (Luiz, 2009. Tir, Momeni, Boboivech 2014. Ismail \& Mahyideen, 2015; Taylor, 1998). The relationship between infrastructure and economic growth is consistent with the theory of exogenous growth (Solow) and is also a concern for endogenous growth theory. The treatment of the first theory by (Barro, 1990) states that economic growth besides being influenced by human resources and the private capital stock is also influenced by government involvement through public capital stock in the form of infrastructure facilities. Also (Aschauer, 1989) measures the productivity of public capital, states that infrastructure is a necessity in encouraging economic growth and increasing productivity.

Infrastructure has a broad role in economic, social and political aspects (Fourie, 2006). The availability of infrastructure at the national and local levels both in quantity (access to infrastructure) and quality (infrastructure or service conditions) is important in supporting economic activities (World Bank, 1994). So that its inadequate availability is one of the causes of the lagging of an area (Todaro \& Smith, 2012). Between developed and developing countries, infrastructure access (quantity and quality) in developing countries are still lagging behind developed countries, so that the increase in infrastructure development in developing countries is considered as the main pillar at the national level (Gurara et al., 2017). As in Indonesia as one of the developing countries in Asia, infrastructure in recent years has become a strategic policy as an effort to accelerate the economy. Based on the Government of Indonesia's expenditure in infrastructure around 1.5\% - 3\% of GDP during the study period, including physical infrastructure such as energy, transportation, telecommunications, water, sanitation, etc., and social infrastructures such as education and health. The figure is relatively small, but nominally during the study period, there was a phenomenon of an increase in infrastructure budget reaching 56\% in 2015, continuing until 2017.

Large-scale expenditure in infrastructure is an effort to pursue high and equitable economic growth. Also, Indonesia prioritizes infrastructure development to catch up with global competitiveness. Quoting from the World Economic Forum, the World Bank stated that among the 12 pillars of world competitiveness, one of them is influenced by infrastructure. Indonesia ranks 62 out of 
140 countries in the infrastructure pillar. The low rating is also a constraint in achieving economic growth. From these observations, motivated researchers to see the role of infrastructure in Indonesia's economic growth. This research was built on the theory and previous empirical studies of infrastructure and economic growth. Previous studies have had on the impact of infrastructure (especially physical infrastructure) on cross-national economic growth with different approaches. Some general empirical evidence concludes that infrastructure such as energy, transportation, telecommunications, and water play an important role in driving the economy of a country (Barro, 1990; Kodongo \& Ojah, 2016; Shi, Guo, \& Sun, 2017; David, 2017). Even the World Bank (1994) states that the average increase in infrastructure by $1 \%$ will increase by $1 \%$ in gross regional domestic products.

This study estimates infrastructure by expanding understanding of the variety of infrastructure used, following Shi et al., 2017; Kodongo and Ojah, 2016; Ismail and Mahyideen, 2015. Four types of infrastructure, namely roads, energy, and telecommunications are estimated using physical size. The study uses regional (provincial) levels because the conditions of geographical, economic and social heterogeneity and the infrastructure needs of all Indonesian provinces are different. The findings of this study will indicate the type of infrastructure that has a major contribution to economic growth, in the future, it can be used as a reference in priority infrastructure development policies in Indonesia. As a consequence, this research is organized as follows: Section 2 presents a theoretical background about public capital (infrastructure) and the basic model of infrastructure relations with economic growth. Section 3 presents a description of the data. Section 4 presents the econometric model of economic growth. Section 5 presents the empirical results. Section 6 conclusions.

\section{LITERATURE REVIEW AND EMPIRICAL FRAMEWORK}

The availability of public capital is part of government spending known as "public infrastructure investment". The capital is not purchased by private companies or individuals. This type of capital purchase adds to public infrastructure and thus contributes to the economic productive potential. Public infrastructure investment is very important in the functioning of the modern economy. Without the support of adequate facilities and infrastructure such as roads for the construction of goods, production will below. Public infrastructure investment increases the portion of government purchases (G) in GDP so that more GDP is generated (Taylor, 1998). One of the public capital's infrastructure is a supporting factor for the country's economy. Many benefits, especially in economic growth and provide positive externalities in various aspects. Based on the concept, infrastructure is defined as capital goods and their position as additional capital in addition to the stock of private capital. Some literature estimates the contribution of public capital (infrastructure) with significant results on the economy. The distribution of infrastructure has the economic infrastructure and social infrastructure. Economic infrastructure such as energy, transportation, telecommunications, and water are fundamental to all types of household activities and economic production (Palei, 2015). Whereas social infrastructure including education and health is the basis for human development (skill).

Several models have been used to see the relationship of infrastructure to economic growth. In general, using growth models with mathematical equations derived from the Cobb-Douglas production function (Mankiew, 2007). The equation

$$
Y_{t}=A_{t} K_{t}^{\alpha} L_{t}^{1-\alpha}
$$

$0<\alpha<1$. Where $\mathrm{Y}$ is GDP, $\mathrm{L}$ is labor, and $\mathrm{K}$ is the capital stock, $\mathrm{A}$ is technology, the conditions differ from country to country which is non-rival (Barro \& Sala-Martin, 1990).

In stimulating economic growth, infrastructure capital can be located as an input that has a direct impact through the expansion of infrastructure that drives technological progress. From another perspective, infrastructure has provided services needed by the community, so that future increases in infrastructure capital will reduce poverty (Frone, 2014). Infrastructure influences efficiency, equity, and the environment. The influence of infrastructure on efficiency is expressed by (Fourie, 2006 \& Agenor, Moreno, Dodson, 2006). First, infrastructure reduces input costs in the production process, called direct impacts or "direct effects" that are used to explain the effects of growth in public capital.

Second, infrastructure improves the productivity of input factors, called indirect effects. High capital stock in infrastructure tends to increase the productivity of other inputs such as private capital and labor. The effect given depends on the initial size of public capital. Mathematically it is generally described through the Cobb-Douglas production function. Also, the indirect impact can be seen in the prices of consumer goods at the domestic level relative to the prices of imported goods. Increased infrastructure investment will increase aggregate demand and reduce domestic prices. Thirdly, the impact of infrastructure on regional economic growth explained through the infrastructure development process starts from the beginning of the construction period until the infrastructure is ready for use. Many job creation in the construction sector and other related sectors. Infrastructure investment also requires maintenance to increase the creation of long-term employment around infrastructure projects. Also, infrastructure investment creates positive externalities in four areas, namely trade, competitiveness, regional integration, and tourism. Because of infrastructure, the country's capacity in international trade has also increased (World Bank, 1994).

Data on infrastructure capital stock is very limited, especially in developing countries. There are two types of capital stock calculations based on the empiric study, namely using monetary values and physical measurements. The use of monetary value through investment value requires data with a long time series, in addition to estimating into the form of stock of public capital, 
depreciation and service life are known as the perpetual inventory method (Romp \& aan, 2014). Because of limited data, Fernald (1999), Kamps (2005b) made alternatives to using physical measurements through several indicators based on the type of infrastructure. According to him, these measurements are more effective because they pay attention to investment networks, so that they are not concerned about who the infrastructure is built (Fernald, 1990). In general, many researchers who use, such as (Calderna et al., 2011) state that monetary value is related to politics, making it vulnerable to the level of corruption. Given the condition of countries with many regions, weak institutions will reduce the effectiveness of public investment (Cavallo, 2010).

Although there are studies that use monetary values as aggregate investment flows, such as (Kemerling \& Stephan, 2002; Indonesian PU Ministry R \& D, 2015. In general, using physical measurements. The importance of infrastructure availability has the attraction for researchers to review its contribution to economic growth Many cross-country studies with different approaches, Kodongo and Ojah (2016) estimated the economic growth model by including public capital infrastructure (roads, water, electricity, telecommunications) in 45 Sub-Saharan Africa countries during the period 2000-2011. in the model, the result is important infrastructure access in economic growth and its quality is indirectly related to growth through export diversification. Shi et al. (2017) investigated the relationship of infrastructure capital to the economic growth of 30 provinces in China, such infrastructure (roads, electricity, railway, telecommunications) the results are increasing show that all infrastructure has a positive contribution to growth, except road infrastructure which provides a significant negative.

Calderóna, Moral-Benitob, \& Servén (2011) evaluated the contribution of infrastructure to aggregate output in 88 developing and rich countries in the 1996-2000 period, they provided evidence of a high level of significance. Elasticity at the country level varies, due to differences in the marginal productivity of infrastructure. Calderon and Serven (2002) estimated the contribution of infrastructure to aggregate output, using state panels in the US from 1960 to 1997, the result of which capital infrastructure (roads, electricity, telecommunications) had a positive contribution to aggregate output. There are studies that pay attention to the direction of infrastructure relations in the economy, such as David (2019) estimating the reciprocal relationship between telecommunications infrastructure on economic growth and development, 46 countries in Africa from 2000-2015, the result of which is the causality of telecommunications infrastructure and growth and development requires telecommunications, on the other hand, the increase in telecommunications infrastructure increases aggregate output.

Several studies expand the effect of infrastructure at the sectoral level and focus on certain infrastructures, such as Rahman and Mamun (2017) focusing on telecommunications infrastructure on the aggregate output of agriculture in China. Tir et al. (2013) focus on water infrastructure (clean water and sewerage) in four agricultural, industrial, service and mining sectors in Iran. Frone (2014) focuses on water infrastructure in Romania. Duflo and Pande (2007) focus their research on dam infrastructure. Fernald (1990) states that the road infrastructure in the aggregate output of manufacturing. They found that there was a relationship between public capital and the increase in sectoral production output. The global level (Zahra, 2008) focuses on telecommunications infrastructure on economic development in Pakistan, telecommunications plays an active role in economic growth, but is still weak at the rural level because of low human resources.

\section{CONCEPTUAL FRAMEWORK}

There have been many studies that have influenced the influence of infrastructure capital on economic growth in several developed and developing countries. Generally using the Cobb-Douglas production function equation. The equation :

$$
Y_{i t}=A_{t} K_{i t}^{\alpha} L_{i t}^{1-\alpha}
$$

Where $\mathrm{Y}$ is output by GDP, $\mathrm{K}$ is capital stock $\mathrm{L}$ is labor, and $\mathrm{A}$ is technology. $\alpha, \beta, \gamma$ is the assumed parameters in terms of return to scale. Sceara generally studies that explain the development of technology by the exogenous Solow model (Barro, 1990). In the research model, we assume infrastructure capital affects economic growth through the expansion of infrastructure that encourages technological progress to follow (holtz-eakin \& Schwartz, 1995; Shioji, 2001; Saidi (2018) :

$$
A=\theta \cdot G^{\gamma}
$$

The symbol $\mathrm{G}$ is public infrastructure capital. The above equation shows that the level of technology is influenced by public capital infrastructure and its growth is assumed to be time-invariant constant. Next equation (3) substitutes into equation (2), so that the production function equation becomes :

$$
Y_{i t}=\theta G_{i t}^{\gamma} K_{i t}^{\alpha} L_{i t}^{1-\alpha}
$$

If both sides of the equation are expressed as per capita, labor is constant:

$$
y_{i t}=k_{i t}^{\alpha} g_{i t}^{\gamma}
$$

$\gamma$ is infrastructure elasticity. Furthermore, both sides of the equation are transformed in the form of natural logs, empirically similar to the GMM dynamic panel model :

$$
\ln \left(y_{i t}\right)=a+\delta_{0} \ln \left(y_{i t-1}\right)+\alpha \ln \left(k_{i t}\right)+\Sigma \gamma\left(g_{i t}\right)+u_{i t}
$$


Where in the panel set $u_{i t}=\mu_{\boldsymbol{i}}+v_{\boldsymbol{t}}$ is an individual effect, $v_{\boldsymbol{t}}$ is a time effect. This study used 34 provinces, $\mathrm{i}=1,2, \ldots, 34$ and 7 years, $\mathrm{t}=1,2, \ldots, 7$. We focus on the growth of output, therefore $k_{i t}$ is the growth rate of GDP per capita, k_it is the private capital stock per capita, $g_{i t}$ is public capital (infrastructure), which consists of :

$$
\Sigma g^{\gamma}=\text { road }+i c t+\text { listrik }+ \text { air }
$$

All variables are in the form of logs except water and telecommunications.

$$
\begin{array}{r}
y_{i t}=a+\delta_{0} y_{i t-1}+\alpha \ln \left(k_{i t}\right)+\gamma_{1} \ln \left(\operatorname{road}_{i t}\right)+\gamma_{2} \ln \left(\text { ict }_{i t}\right)+\gamma_{3} \ln \left(\text { energy }_{i t}\right) \\
+\gamma_{4}\left(\text { air }_{i t}\right)+\mu_{i}+v_{t}
\end{array}
$$

Dynamic panels occur two problems, namely autocorrelation or endogeneity and individual effects or heteroscedasticity because there is a lag of the dependent variable $y_{i t-1}$ which is the regressor on the right side correlated with the error component. So if an estimate is used using the OLS approach, both fixed effect (FE) within transformation and random GLS effect, then it produces biased and inconsistent estimates.

An alternative to solving the problem of endogeneity is using the instrumental variable (IV) approach. This approach is consistent but inefficient in the model because it does not pay attention to other conditions, namely the problem of heterocedasticity or individual effects (Baltagi, 2005). Arellano-Bond suggests the generalized method of moment (GMM) method. There are two types of GMM estimates, namely the difference and the GMM system. Both have two estimation options, one-step, and two-step. Using several internal instruments in the form of level and lag. Therefore to test the validity of the instruments used will be carried out the Hansen test. Whereas to test autocorrelation used serial autocorrelation (AR) tests (Roodman, 2009).

\section{DATA DESCRIPTION}

The data used in this study came from various sources, the Indonesian Central Bureau of Statistics, the ministry of energy, water and mineral resources, especially the publication of gross regional domestic product statistics, statistics on land transportation, telecommunications statistics, statistics on clean water. Annual data from 2011 to 2017 are used in this analysis consisting of 34 provinces in Indonesia. This study uses one dependent variable by real GDP per capita (y) based on constant prices in 2010 and several independent variables. The description of the data is presented in the table.

The first independent variable is capital stock non-infrastructure. The capital stock data is based on gross fixed capital formation data at constant prices adjusted for depreciation rates, otherwise known as the perpetual inventory method approach (Appendix 1.). The second variable is public capital (infrastructure) (g) consisting of road infrastructure, telecommunications, energy. The measurement uses indicators. Road indicators, namely the quantity of roads that show the length of the road (national, provincial, district / city) in kilometers excluding expressways and road quality which shows the percentage of paved roads to the total road length, following (Ismail \& Mahyideen, 2015; Straub \& Terada, 2010 ; Kodongo \& Ojah, 2014; Lall, 2007).

Telecommunications infrastructure according to the International Telecommunications Communication Union, measurement through teledensity index which consists of three components, namely fixed telephone access, mobile telephone access, internet access. Because of the availability of data, this study only uses mobile phone access, following (Rahman \& Mamun, 2007, Calderon \& Serven, 2010). The main water focus infrastructure in AI is clean, the indicator is the percentage of the population with clean access, following (Straub \& Terada, 2010). Energy infrastructure uses installed electrical capacity (kilowatts) to follow (Shi at al., 2017; Straub \& Terada, 2010).

Table 1. Variable definitions

\begin{tabular}{ll}
\hline \multicolumn{1}{c}{ variable } & \multicolumn{1}{c}{ description } \\
\hline rowt & log real gdp per capita (million) (constant price 2010) \\
lncapital & log capital stock per worker (100 million) \\
lnroad & log length of road (km per million persons) \\
paved road & persentase jalan beraspal teradap total jaringan jalan \\
telecommunication & percentage mobile phone subscriber \\
water & percentage populasi with access to improved sources of water \\
lnelectricity & log electricity generating capacity per million worker \\
\hline
\end{tabular}

\section{EMPIRICAL RESULTS AND DISCUSSION}


Table 2. gives the results of the relationship between the dependent variable (economic growth) and the independent variable (non-infrastructure capital stock, public infrastructure capital stock). Economic growth shows a significant correlation with each measurement of infrastructure. All parameter estimates are significant at different levels 1\%, 5\%, and 10\%. The four types of infrastructure are explanatory power in the model.

Table 2. Result Estimation

\begin{tabular}{|c|c|c|c|}
\hline & Koefisien & Std.error & Prob. \\
\hline L.growt & $0.9 * * *$ & 0.005 & 0.000 \\
\hline Instock & $0.013^{* * *}$ & 0.003 & 0.000 \\
\hline Lnjalan & $0.001 * * *$ & 0.001 & 0.000 \\
\hline paved & $0.001 * * *$ & 0.001 & 0.0 \\
\hline air & $0.002 * * *$ & 0.000 & 0.000 \\
\hline ictmobile & $0.004^{* *}$ & 0.000 & 0.053 \\
\hline Inenergy & -0.001 & 0.001 & 0.576 \\
\hline$p$-value & & & \\
\hline$A R(1)$ & 0.249 & & \\
\hline$A R(2)$ & 0.321 & & \\
\hline $\begin{array}{l}\text { Hansen } \\
\text { p-value }\end{array}$ & 0.213 & & \\
\hline
\end{tabular}

z statistic in parameters :

$$
\begin{aligned}
& * \mathrm{p}<0,1 \\
& * * \mathrm{p}<0,05 \\
& * * * \mathrm{p}<0,01
\end{aligned}
$$

The table above gives estimation results using the system generalized method of moment (GMM) model, with a two-step estimation. Although it is different from researchers in general who use one-step, follow (Windmeijer, 2005) that two steps correct errors that are quite strong than one step.

All relevant variables have been considered, but a number of them have a different significant impact on real GDP per capita. Surprising results on road infrastructure were negatively significant as opposed to Maryaningsih et al. (2011) study in Indonesia. But these results are relevant to the research of Shi et al. (2017). According to them, this significant negative can be explained through the U-shaped relationship between infrastructure investment and growth which indicates the existence of the "crowding out effect" of private capital when the infrastructure investment is too dominant. The composition of the private sector in infrastructure development is approximately $10 \%$ in Indonesia. Access to the road network does provide easy access to economic activities, but the financing strategy needs to be considered because the risks that arise are many large infrastructure investments with a long life but slow revenue streams that affect public finance (World Bank, 1994).

Another infrastructure (telecommunications and water) provides positive and significant evidence following previous research, but its contribution varies. Telecommunications infrastructure stated in the indicator of mobile phone use, provides a positive coefficient of 0.004 , meaning that if the use of cellular telephones increases 10 percent, it will increase economic growth by 0.04 percent. In the era of globalization, it is closely related to the increased use of cellular phones. The increase in the use of cellular telephones in Indonesia shows that the telephone network coverage has expanded to the rural area. So far the government and the private sector have sought telecommunications networks evenly in all regions with the construction of tower base trasnsciver stations (BTS). Quality telecommunications infrastructure will enable producers, businesses, communities to obtain information and knowledge (Ismail \& Mahyideen, 2015). Also, according to Frone (2016), telecommunications infrastructure can increase community innovation and help facilitate trade so that it ultimately has the potential to increase economic growth. 
Water infrastructure provides positive and significant evidence. The implication is that increasing the availability of clean water infrastructure and increasing the population connected with these services can lead to economic growth (GDP per capita growth) at the regional (county) level. A positive coefficient of 0.002 means that if access to water rises 10 percent, it will increase economic growth by 0.02 percent. The numbers are relatively small, but it can be ascertained that the coefficient shows the potential for clean water infrastructure to increase economic growth. Provision of decent clean water by the government is an effort to create a healthy environment because in the future it affects the quality of human resources.

The results of this study are in line with the estimation results found in various countries, although the value is different in essence infrastructure has a positive role in supporting the country's economic growth. This difference occurs because of differences in infrastructure investment efficiency and infrastructure characteristics in economic activities (World Bank, 1994).

Table 3. Previous Research

\begin{tabular}{|c|c|c|c|c|}
\hline Study & Object & Approach & Variable & Conclusion \\
\hline Saidi (2018) & $\begin{array}{l}\text { MENA } \\
\text { coutries, 2006- } \\
2016\end{array}$ & $\begin{array}{l}\text { Growt model. } \\
\text { Panel GMM }\end{array}$ & $\begin{array}{l}\text { Public capital : } \\
\text { Transportation } \\
\text { (road) }\end{array}$ & Elasticity road is $0.21 \%$ \\
\hline Lall (2007) & $\begin{array}{l}24 \text { state in } \\
\text { India }\end{array}$ & $\begin{array}{l}\text { Growt model. } \\
\text { Panel statis }\end{array}$ & $\begin{array}{l}\text { Public infrastructure } \\
\text { : trasnposrt, } \\
\text { communication, } \\
\text { power supply, water } \\
\text { and sanitation }\end{array}$ & $\begin{array}{l}\text { Elasticity transport and } \\
\text { communication is } 0.51 \% \\
\text { Power supply is } 0.16 \\
\text { Water and sanitation is } \\
0.07 \%\end{array}$ \\
\hline $\begin{array}{l}\text { Ismail and } \\
\text { Mahyideen } \\
\text { (2015) }\end{array}$ & $\begin{array}{l}\text { Country in } \\
\text { Asia, 1971- } \\
2013\end{array}$ & $\begin{array}{l}\text { Growth model. } \\
\text { Panel statis }\end{array}$ & $\begin{array}{l}\text { Public capital: } \\
\text { transport } \\
\text { infrastructure, } \\
\text { information and } \\
\text { telecomunication }\end{array}$ & $\begin{array}{l}\text { Elasticity paved road is } \\
0,5 \% \\
\text { Telephone line and mobile } \\
\text { phone is } 0,1 \% \\
\text { Internet facility is } 0,2 \%\end{array}$ \\
\hline $\begin{array}{l}\text { Calderóna, } \\
\text { Moral-Benitob, } \\
\text { \& Servén, (2011) }\end{array}$ & $\begin{array}{l}88 \text { industrial } \\
\text { and } \\
\text { developing } \\
\text { countries, } \\
1960-2000\end{array}$ & $\begin{array}{l}\text { Aggregate } \\
\text { production } \\
\text { function } \\
\text { framework. } \\
\text { Panel GMM }\end{array}$ & $\begin{array}{l}\text { Public capital } \\
\text { transportation, } \\
\text { telecomunication }\end{array}$ & $\begin{array}{l}\text { Output elascticity in a } \\
\text { range between } 0,07-0,10\end{array}$ \\
\hline David (2019) & $\begin{array}{l}46 \quad \text { African } \\
\text { countries, } \\
2000-2015\end{array}$ & $\begin{array}{l}\text { Neo-classical } \\
\text { growth theory. } \\
\text { Panel statis }\end{array}$ & $\begin{array}{l}\text { Public capital : } \\
\text { telecomunication }\end{array}$ & $\begin{array}{l}\text { Elasticit composit index } \\
\text { telecommunication is } 0,06\end{array}$ \\
\hline Shi at al. (2017) & $\begin{array}{l}30 \text { Province in } \\
\text { China, 1990- } \\
2013\end{array}$ & $\begin{array}{l}\text { Production } \\
\text { function. } \\
\text { Panel GMM }\end{array}$ & $\begin{array}{l}\text { Public capital : } \\
\text { Infrastructure road, } \\
\text { rail, electricity, } \\
\text { phone }\end{array}$ & $\begin{array}{l}\text { Elasticity electricity } 0,07 \\
\text { is } 0,5 \% \\
\text { Telephone line and mobile } \\
\text { phone is } 0,01 \% \\
\text { Rail is } 0,03 \\
\text { Negative sig }-0,05 \text { on the } \\
\text { road can be explained } \\
\text { through "U-Shaped" }\end{array}$ \\
\hline $\begin{array}{l}\text { Maryaningsih at } \\
\text { al. (2014) }\end{array}$ & $\begin{array}{l}33 \text { Province in } \\
\text { Indonesia, }\end{array}$ & $\begin{array}{l}\text { Neo-classical } \\
\text { growth theory. } \\
\text { Penel GMM }\end{array}$ & $\begin{array}{l}\text { Public capital : } \\
\text { transportation (road, } \\
\text { port) and } \\
\text { enlectricity . }\end{array}$ & $\begin{array}{l}\text { Elasticity quantity road is } \\
0,03 \% \\
\text { Electricity is } 0,08 \% \\
\text { Port is } 0,01 \%\end{array}$ \\
\hline
\end{tabular}

Indonesia is a country that has many islands characterized by conditions of geographical, economic and social diversity. Therefore, the Indonesian government must determine the priority of infrastructure development that is appropriate and equitable. Therefore finally we can conclude that all infrastructure is important and has an impact in different ways at different places. Everything will be a tool in helping to increase economic growth.

\section{CONCLUSION}

Indonesia is one of the developing countries in Southeast Asia that seeks infrastructure development to achieve high economic growth and catch up with the country's competitiveness at the global level. The estimation results show that all explanatory infrastructure variables have a significant positive effect except road infrastructure. These results indicate that not all infrastructure is good, excessive development of infrastructure will lead to poor growth. Therefore, it takes an approach and 
determining the right priority scale in infrastructure development to produce growth accompanied by equity. The significant negative path is not surprising because previous researchers Shi et al. (2017) also found similar results in China.

All other infrastructure (telecommunications and water) estimation results provide evidence of a positive contribution to economic growth. Although each type of infrastructure has a negative contribution value. This finding is consistent with previous studies in several countries. The difference is only in the amount of contribution due to differences in the efficiency of infrastructure investment. Finally, it can be concluded that infrastructure is evident in Indonesia with the potential to increase economic growth.

\section{REFFERENCES}

1. Agénor, P.-R., \& Moreno-Dodson, B., "Public Infrastructure and Growth: New Channels and Policy Implications", Ssrn, 2006. https://doi.org/10.2139/ssrn.2005043

2. Arezki, R., Candelon, B., \& Sy, A. N.. "Is Infrastructure Capital Productive? A Dynamic Heterogeneous Approach," Journal of Applied Econometrics, 47(4), 36-37, 2014. https://doi.org/10.1002/jae

3. Baltagi, Badi H., "Econometric analysis of panel data ( $3^{\text {rd }}$ ed.)," England : John Wiley \& Sons Ltd, 2005.

4. Barro, R. J., "Government Spending in a Simple Model of Endogeneous Growth," Journal of Political Economy, 98(5, Part 2), S103-S125, 1990. https://doi.org/10.1086/261726

5. Berlemann, M., \& Wesselhöft, J.-E., "Estimating Aggregate Capital Stocks Using the Perpetual Inventory Method - New Empirical Evidence for 103 Countries,"Helmet Schmidt Universitat - Working Paper No. 125, 1-37.

6. Calderón, C., \& Servén, L., "The Output Cost of Latin America's Infrastructure Gap," The Limits of Stabilization: Infrastructure, Public Deficits, and Growth in Latin America, 95-118.

7. Calderóna, C., Moral-Benitob, E., \& Servén, L., "Is infrastructure capital productive? A dynamic heterogeneous approach," Policy Research Working Paper; No. WPS 5682, 1(1), 2011. Retrieved from http://documents.worldbank.org/curated/en/990231468331034266/Is-infrastructure-capital-productive-a-dynamicheterogeneous-approac

8. Cavallo, E., \& Daude, C., "Public investment in developing countries: A blessing or a curse?" Journal of Comparative Economics, 39(1), 65-81, 2011. https://doi.org/10.1016/j.jce.2010.10.001

9. David, O. O., "Nexus between telecommunication infrastructures, economic growth and development in Africa: Panel vector autoregression (P-VAR) analysis," Telecommunications Policy, (March), 1-17, 2019. https://doi.org/10.1016/j.telpol.2019.03.005

10. Duflo, E., \& Pande, R., "Dams," The Quarterly Journal of Economics, 122(2), 601-646, 2007. https://doi.org/10.3386/w11711

11. Fourie, J., "Economic infracstructure: A review of definitions, theory and empirics," South African Journal of Economics, 74(3), 530-556, 2006. https://doi.org/10.1111/j.1813-6982.2006.00086.x

12. Frone, S., \& Frone, D. F., "Challenges in Analyzing Correlation between Water Infrastructure and Economic Development," Procedia Economics and Finance, 10(14), 197-206, 2014. https://doi.org/10.1016/S22125671(14)00294-9

13. Gurara, D., Klyuev, V., Mwase, N., Presbitero, A., Xu, X. C., \& Bannister, G., "Trends and Challenges in Infrastructure Investment in Low-Income Developing Countries," IMF Working Papers, 17(233), $1,2017$. https://doi.org/10.5089/9781484324837.001

14. holtz-eakin, D., \& Schwartz, A. E. Infrastructure in a structural model of economic growth. RRegional Science and Urban Econimies, 25, 131-151, 1995.

15. IMF Annual Report 2018, 2018.

16. Ismail, N. W., \& Mahyideen, J. M., "The Impact of Infrastructure on Trade and Economic" Asian Development Bank Institute.

17. John G. Fernald, "Roads to Prosperity? Assessing the Link between Public Capital and Productivity," American Economic Review, 89(3), 619-638, 1999.

18. Kamps, C., "New Estimates of Government Net Capital Stocks for 22 OECD Countries 1960-2001," Ssrn, July 2002. https://doi.org/10.2139/ssrn.752984

19. Kamps, C., "The dynamic effects of public capital: VAR evidence for 22 OECD countries," International Tax and Public Finance, 12(4), 533-558, 2005. https://doi.org/10.1007/s10797-005-1780-1

20. Kemmerling, A., \& Stepan, A., "The Contribution of Local Public Infrastructure to Private Productivity and its Political Economy: Evidence from a Panel of Large German Cities," Public Choice, 113(3-4), 403-424, 2002. https://doi.org/https://doi.org/10.1023/A:1020821624682

21. Kodongo, O., \& Ojah, K., "Does infrastructure really explain economic growth in Sub-Saharan Africa?" Review of Development Finance, 6(2), 105-125, 2016. https://doi.org/10.1016/j.rdf.2016.12.001

22. Kumari, A., \& Sharma, A. K., "Physical \& social infrastructure in India \& its relationship with economic development," World Development Perspectives, 5, 30-33, 2017. https://doi.org/10.1016/j.wdp.2017.02.005

23. Lall, S. V., "Infrastructure and regional growth, growth dynamics and policy relevance for India," Annals of Regional Science, 41(3), 581-599, 2007. https://doi.org/10.1007/s00168-006-0112-4

24. Maryaningsih, Novi Hermansyah, O., \& Savitri, M., "Influence of Infrastructure on Economic Growth in Indonesia," 
Bulletin of Monetary and Banking Economics, 17(1), 2014. Retrieved from https://www.bi.go.id

25. Palei, T., "Assessing the Impact of Infrastructure on Economic Growth and Global Competitiveness," Procedia Economics and Finance, 23, 168-175, 2015. https://doi.org/10.1016/s2212-5671(15)00322-6

26. Rahman, M. M., \& Mamun, S. A. K., "The effects of telephone infrastructure on farmers' agricultural outputs in China," Information Economics and Policy, 41, 88-95, 2017. https://doi.org/10.1016/j.infoecopol.2017.06.005

27. Roodman, D., "How to do xtabond2: An introduction to difference and system GMM in Stata," The Stata Journal, 9(1), 86-136, 2002. Retrieved from http://stata-journal.com

28. Saidi, S., Shahbaz, M., \& Akhtar, P., "The long-run relationships between transport energy consumption, transport infrastructure, and economic growth in MENA countries," Transportation Research Part A: Policy and Practice, 111(January), 78-95, 2018. https://doi.org/10.1016/j.tra.2018.03.013

29. Shi, H., \& Huang, S., "How much infrastructure is too much? A new approach and evidence from China," World Development, 56, 272-286, 2014. https://doi.org/10.1016/j.worlddev.2013.11.009

30. Shi, Y., Guo, S., \& Sun, P., "The role of infrastructure in China's regional economic growth," Journal of Asian Economics, 49, 26-41, 2017. https://doi.org/10.1016/j.asieco.2017.02.004

31. Shioji, E., "Public capital and economic growth: A convergence approach," Journal of Economic Growth, 6(3), 205-227, 2001. https://doi.org/10.1023/A:1011395732433

32. Straub, S., \& Terada-hagiwara, A., "ADB Economics Working Paper Series Infrastructure and Growth in Developing Asia," ADB Economics Working Paper Series, (186), 1-53, 2010.

33. Tir, N. A., Momeni, F., \& Boboevich, G. T., "Exploring the Effects of Water Sector Investment in Economic Development in Iran," Procedia - Social and Behavioral Sciences, 131(5), 396-405, 2014. https://doi.org/10.1016/j.sbspro.2014.04.137

34. Windmeijer, F., a finite sample correction for the variance of linear two-step GMM estimators," Journal of Econometric, 126, 25-51, 2005.

35. World Bank, "World Development Report 1994. Infrastructure for Development," In World Development , Vol. 26, 1994. https://doi.org/10.1016/S0305-750X(98)90001-8

36. Zahra, K., Azim, P., \& Mahmood, A., "Telecommunication infrastructure development and economic growth: A panel data approach," Pakistan Development Review, 47(4), 711-726, 2014.

\section{Appendix 1. Estimated capital stock}

The capital stock is built with the perpetual inventory method. This method is commonly used in research because it is simple and does not require expensive fees, such as. $K_{t}=(1-\delta) K_{t-1}+I_{t} \cdot K_{t-1}$ is the initial capital stock. $I_{t}$ is an investment. To implement the perpetual inventory method, we need three components of data: investment, information on initial capital stock, and information on the depreciation rate of capital stock. First, the investment is based on the PMTB database, capital stock analysis follows Kamps (2006) assuming an annual investment growth rate of 4\% with the base year of 2010, the three constant assumptions depreciation rates of 5\% follow (Shi at al. 2017). 